Estudios de

lingüistica inglesa aplicada

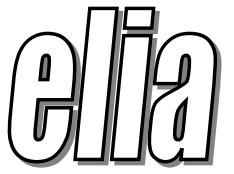

\title{
THE DISTINCTIVE NATURE OF TASK REPETITION IN WRITING. IMPLICATIONS FOR THEORY, RESEARCH, AND PEDAGOGY
}

\section{Rosa M. Manchón}

University of Murcia, Spain

manchon@um.es

DOI: http://dx.doi.org/10.12795/elia.2014.i14.02

This paper looks into the distinctive nature of task repetition (TR) in the environment of L2 writing and the potential language learning benefits that may derive from implementing various forms of TR. The main argument put forward is that it is theoretically and pedagogically relevant to problematize and expand current understandings of $T R$ in the realm of oral tasks on account of both the defining characteristics of written communication, and the idiosyncrasy of the "external" and "internal" task repetition dimensions of writing tasks. The argument is constructed on the basis of three building blocks: (i) an analysis of the concept of TR as currently conceptualized and researched in the TBLT theoretical and empirical literature, and a review of the empirical literature on the nature and observed effects of TR in the oral modality; (ii) a discussion of the nature and potential effects of TR in the written modality, and, on the basis of the two previous building blocks, (iii) a reflection on implications for refinements in TBLT theorizing and for the expansion of empirical research agendas. 
Key words: task repetition, L2 writing, writing-to-learn, internal task repetition, external task repetition, feedback

Este trabajo presenta una reflexión sobre las características definitorias del procedimiento conocido como Repetición de la tarea (RT) en la modalidad escrita, así como los posibles efectos que sobre el aprendizaje lingüistico puedan derivarse de la puesta en marcha de distintas formas de RT. La tesis defendida es que es relevante desde las perspectivas teórica y aplicada reconsiderar los planteamientos actuales sobre la $R T$ en lo que respecta a tareas orales sobre la base tanto de las características definitorias de la comunicación escrita, como de la idiosincrasia de las variedades de RT "externa" e "interna" que caracterizan tareas es la modalidad escrita. Estas ideas se desarrollan sobre la base de tres pilares: (i) un análisis de los planteamientos teóricos y la investigación empirica de la RT en el ámbito de la comunicación oral, (ii) una discusión de la naturaleza y los efectos que potencialmente puedan derivarse de la repetición de tareas escritas y, sobre la base de los dos pilares anteriores, (iii) una reflexión sobre las posibles implicaciones para ulteriores desarrollos en la reflexión teórica y la investigación empirica.

Palabras clave: Repetición de la tarea, escritura en segundas lenguas, escribir para aprender, repetición interna de la tarea, repetición externa de la tarea, respuesta al escrito.

\section{Introduction: The Role of Writing in SLA and TBLT Theory and Research}

This paper is intended as a further contribution to recent attempts to make second language (L2) writing more central in second language acquisition (SLA) preoccupations, in general (see Bitchener, 2012; Bitchener \& Ferris, 2012; Manchón, 2011a, 2012, 2014a; Ortega, 2012; Polio \& Williams, 2009; Williams, 2012), as well as in the research framed in the task-based language learning and teaching paradigm (TBLT), in particular (cf. contributions in Byrnes \& Manchón, 2014a). More specifically, I will look into the language learning potential of L2 writing with a discussion of the nature

ELIA 14, 2014, pp. 13-41 DOI: http://dx.doi.org/10.12795/elia.2014.i14.02 
and potential learning effects of task repetition (TR), a task implementation variable that has attracted considerable attention in TBLT theoretical, empirical, and pedagogical scholarship (cf. Bygate, 2006). However, given the evident predominance of orality in TBLT studies (see Byrnes \& Manchón, 2014b), an almost exclusive focus on oral communication characterizes research on TR, hence the relevance of expanding current accounts of TR with a focus on writing tasks. After all, as recently argued (cf. Bynes \& Manchón, 2014b; Manchón, 2014b), no sound reasons can be adduced to exclude written communication from "the various domains of lifetime endeavor outside the language classroom" (Robinson, 2011, p. 11) and the "full complexity of real-world target-task performance" (Robinson \& Gilabert, 2013, p. 3) that TBLT theory, research, and pedagogy claim to be concerned with. What is more, if TBLT approaches to language learning and teaching ultimately aim at maximizing learning opportunities in instructed SLA, it makes all theoretical and practical sense to explore the learning opportunities potentially afforded by all language modalities. In this respect, Bygate, van den Branden and Norris (2014: ix) rightly note that each modality shows its own distinctive nature as a consequence of the equally distinct "meaning-making spaces [...] for teaching and learning" that each modality potentially affords. In their own words:

One fundamental premise of TBLT is that tasks create a need to mean both in terms of creating a semantic space and a demand or reason for meaning-making. In the process, tasks lead learners to engage in exploring and elaborating familiar form-meaning mappings, and in making new ones [...] Tasks then are intended to have a material impact on the kinds of meaning-making processes that students engage in, at the same time contextualising and motivating the language features they work with. It follows from this fundamental idea that written as opposed to oral tasks can be expected to open up distinct meaning-making spaces - textual and interpersonal, as well as semantic - for teaching and learning (Bygate, van den Branden, \& Norris, 2014: ix).

The neglect of writing in TBLT theory and research, in general, and in discussions of TR, in particular, may simply derive from the secondary role that L2 writing has occupied in SLA theorizing and empirical research agendas (see discussions in Byrnes \& Manchón, 2014b; Ortega, 2012). As 
a result, an emphasis on orality and input processing ostensibly overweighs the attention paid by SLA scholars to written language learning and written output practice. Suffice to say that crucial issues of concern in SLA theory and research have been explored primarily in connection with spoken language, be it the role of individual differences (but see Kormos, 2012), the role of implicit and explicit knowledge sources and learning processes (but see Shintani \& Ellis, 2013; Williams, 2012), or current disciplinary debates over complexity, accuracy, and fluency (CAF) measures in their application to L2 performance (cf. Housen, Kuiken, \& Vedder, 2012, but see Norris \& Ortega, 2009; Ortega, 2012). Even theoretical and pedagogically-oriented accounts of the role of output in SLA make only minimal reference, if at all, to written output practice (for instance, Muranoi, 2007, or earlier and later formulations of the Output Hypothesis, cf. Swain, 1985, 1995).

The landscape nevertheless seems to be changing as scholarly interest in writing as a site of language learning has gradually made its way into research agendas in the SLA and TBLT domains, as well as in L2 writing studies. These developments stem in part from the recognition of the theoretical and applied relevance of complementing theory and research on the "learning-to-write" dimension of L2 writing (the prevalent paradigm in L2 writing research, but see Cumming, 1990; Harkalu, 2002; Manchón, 2011a) with the investigation of the "writing-to-learn-language" (WLL) dimension of L2 writing as a central component of future research agendas (see Roca de Larios, 2013). Examples of this gradual broadening of research interests are the special issue of "L2 writing-SLA interfaces" published in the Journal of Second Language Writing in 2012, or the chapters on the WLL dimension of L2 writing included in several forthcoming publications, such as the Handbook of Academic Writing, that will include a chapter on "Language and L2 writing: Learning to write and writing to learn in academic contexts", or the TESOL Encyclopedia of English Language Teaching, which will contain an entry on "Writing as language learning." Interest in exploring the language learning potential of L2 writing has also been generated in the SLA field, where an array of publications have applied SLA lenses to the study of L2 writing (cf. Manchón, 2011b; Ortega, 2011, 2012; Williams, 2012), as well as to 
theoretical and empirical analyses of the provision and processing of feedback (cf. Bitchener, 2012; Bitchener \& Ferris, 2012; Polio, 2012; Shintani \& Ellis, 2013). In addition, a considerable number of book-length treatments of central issues of concern in writing research have made their way into main SLA book series (Manchón, 2009, 2011a, 2012; Storch, 2013), including a TBLT book series. As for the latter, in the Preface to a recent publication on tasks and writing (cf. Byrnes \& Manchón, 2014a), the Series Editors state:

[...] owing to deeply engrained assumptions about the psycholinguistics of second language acquisition and about the immediacy of oral language processing, SLA as a field has generally privileged oral language as a site both for studying and for promoting language learning. In this respect, TBLT research has largely incorporated those same assumptions into empirical approaches to task-based learning. But on exploring closely the role of writing tasks and their rich potential for fostering second language learning and use, it may start to appear less axiomatic that the oral mode should be the privileged site for second language learning and hence for TBLT (Bygate, van den Braden, \& Norris, 2014: p. ix)

This article tries to advance in this new research avenue concerned with the "role of writing tasks and their rich potential for fostering second language learning and use" that Bygate, van den Branden and Norris (2014) allude to. I will do so with a reflection on the nature and potential effects of task repetition in the writing modality in an attempt to discern how such analysis can help us reconfigurate the prevailing theoretical basis of research in the field, and expand the empirical scope of research investigating the task learning that may derive from implementing various forms of TR. In order to do so, the rest of the paper is organized as follows. I shall first elaborate further on the concept of task repetition as currently conceptualized and researched in the TBLT theoretical and empirical literature, and I will introduce a range of questions worthy of attention when the concept of TR is expanded to encompass both the oral and written modalities. I will then review (albeit briefly) the available empirical evidence on the learning effects of task repetition in the oral domain (section 3). Against this background, section 4 will discuss the 
distinctive nature and types of TR in writing and I will examine what we know and what we still need to know about the potential learning effects that may result from implementing TR techniques in writing. The last part of the paper (section 5) will summarize the implications that the preceding discussion of TR in writing has for TBLT theorizing and for TBLT-framed research agendas on TR.

\section{Rationale for the Language Learning Potential of Task Repetition: Oral and Writing Tasks}

As mentioned at the outset, task repetition (TR) is a task implementation variable that has generated a great deal of interest in the TBLT empirical research and pedagogical literature (see Bygate, 2006; Ellis, 2012; Samuda \& Bygate, 2008). The rationale for making TR central in TBLT preoccupations is ultimately related to the general concern of findings ways of promoting attention to language in TBLT-based/oriented pedagogical approaches.

On account of the limitations that the on-line nature of oral communication imposes on the allocation of attentional resources to various task dimensions, crucially including language processing, the central tenet in the TR literature is that giving L2 learners the opportunity to repeat a task offers a favorable scenario for prioritizing a focus on expressing the intended meaning (during the first iteration of the task) while at the same time fostering focus-on-form (FonF) processes (during the repetition of the task), thereby leading to improved performance and promoting optimal conditions for acquisition to take place. These potential learning outcomes are predicated on the assumption that having the opportunity to engage in various forms of TR (to be reviewed in the next section) offers an "opportunity for learners to rework their language when producing the same or similar talk on a second occasion" (Samuda \& Bygate, 2008, p. 114. Italics added). Accordingly, TR is thought to offer "a particularly useful context for learning" (Bygate, 2006, p. 172) because "it can help to give learners space to working on matching meanings to language, and to 
integrate attention to the more redundant features (especially grammatical and phonological) into their speech" (Bygate, 2006, p. 172. Emphasis added). As we will see in the next section, the assumption that TR is an opportunity for learners to engage in deeper linguistic processing, and the hypothesis that this deeper processing can result in task learning as manifested in improved performance, have been put to the empirical test, the general consensus being that TR repetition does foster attention to language and results in increased fluency, accuracy, and complexity of oral production.

The picture nevertheless becomes more complex when we add writing to the mix, especially bearing in mind the distinct nature of the temporal dimension of written communication, on the one hand, and the characteristic features of the provision and processing of feedback in the environment of writing, on the other. This results in unique qualities of TR in the domain of writing.

Regarding time considerations, in contrast to the on-line nature of oral communication, writing, with the exception of synchronous computerassisted communication, always takes place off-line. This means that the processing constraints that derive from engaging in oral communication in real time do not apply to most forms of written communication, which is an issue of crucial implications for considerations of the allocation of attention to language during task execution, and certainly a distinctive characteristic of writing tasks execution worth taking into consideration when discussing potential learning effects of TR across language modalities. In their recent (and unique) study on the long-term effects of TR in writing, Nitta and Baba (2014) contend that "one necessary condition for L2 learning potential, that is, simultaneous engagement in meaning-making and language processing, seems to be more likely to be achieved in writing tasks because of the reduced constraint on processing time during the act of production" ( $p$. 108). In fact, recent general analyses of L2 writing as a site for language learning (cf. Manchón, 2011b, 2014a; Ortega, 2012; Williams, 2012) systematically emphasize the potential language learning associated with 
the greater availability of time that characterizes writing, suggesting that this greater time availability potentially allows L2 writers to devote more time to task conceptualization, task planning, and task completion, three processes closely associated with attention to language-related concerns.

As for the effects of TR in writing, it could be posed that instead of, or in addition to, overcoming time constraints on attention resources (as is the case of TR in speaking) so that attention is freed to attend to language matters, the availability of time that characterizes writing may represent an ideal condition for TR to foster deeper linguistic processing as a result of a gradual "complexification of goals" being pursued. This is so because having more time to plan and formulate messages and being able to go back over what one has written, or over the feedback received on one's own writing (both the written text and the written feedback on one's own writing are always permanent), could in theory allow L2 writers to be more in control of their attentional resources, more prone to prioritize linguistic concerns (in contrast to what is possible in oral production) and, accordingly, more likely to attend to language. It follows that the different processing temporal demands of speaking and writing are likely to result in different effects of TR. However, at the moment these are theoretical predictions in need of further empirical validation.

A second characteristic of writing that also contributes to the distinctive nature of TR in the writing domain is the availability of feedback as part of the task repetition cycle. Interestingly, issues of feedback are conspicuously absent in current discussions of TR, with the exception of analyses of the feedback and scaffolding provided during TR in collaborative situations, and also with the very notable exception of Ellis's (2009) crucial observations as to the potential combined effect of TR and feedback processing in bringing about learning via TR. This is certainly a path worth exploring in any examination of TR in the writing mode because, as Ferris and Hedgcock (2014) rightly note, "Both teachers and students feel that teacher feedback on student writing is a critical, nonnegotiable aspect of writing instruction" (pp. 237-238). Therefore, it does not make much theoretical or pedagogical sense to contemplate 
TR in the environment of writing without considering at the same time the role that the provision and processing of feedback can have in the nature and potential learning outcomes of repeating writing tasks. After all, the rationale for the provision and processing of feedback in writing is precisely to engage the learner in a form of task repetition (the revision of a previously produced text) in which his/her attention is drawn towards those dimensions of the task in need of improvement, such as ideational concerns, textual matters, or language-related dimensions of text production, inter alia. In this respect, as a form of feedback, written corrective feedback (WCF) would direct the learner's attention to language concerns, the main target of TR in the oral domain, as mentioned above. I will revisit these future avenues for research in the concluding section of the paper. I now turn attention to the available empirical research on the nature and observed effects of TR in the oral modality.

\section{The Language Learning Effects of Task Repetition. Empirical Evidence from the Oral Domain}

The available empirical knowledge on TR has been generated in a body of research framed in cognitive approaches to SLA, mainly the FonF paradigm, skill acquisition theory, and the interactional hypothesis. In addition, researchers have also informed their studies by models of speech production, mainly Levelt's (cf. Levelt, 1989), as well as Robinson's and Skehan's theoretical proposals on task-related factors and the potential constraints on the allocation of attentional resources to language during task execution (cf. Robinson, 2007, 2011; Skehan, 1998, 2014).

This TBLT strand has investigated several forms of TR subsumed in Ellis's (2012) characterization of TR as a task implementation variable that entails asking participants to repeat a task "without any changes to the task or by modifying the design of the task or by manipulating one of the other implementation variables" (Ellis, 2012, p. 202). Accordingly, three main types of task repetition have been empirically investigated: exact TR, content TR, and procedural TR. Studies investigating exact task repetition have asked participants to perform a task and then repeat it after a time lapse, 
ranging from days to weeks (cf. Bygate, 1996, 2001; Bygate \& Samuda, 2005). This type of TR would correspond to Ellis's TR modality that entails no changes to the task. Other studies investigating this TR modality have introduced slight variations, such as the inclusion of an intervening FonF stage between the first iteration of the task and its repetition (cf. Hawkes, 2011), or the comparison between exact task repetition and planning implementation variables (cf. Ahmadian \& Tavakoli, 2010).

In contrast, the possible modifications in TR implementation mentioned in Ellis's characterization of TR have been operationalized in empirical research as "content" TR (cf. Gass, Mackey, Alvarez-Torres, \& Fernández-García, 1999; Lynch \& Maclean, 2000) and "procedural” TR (cf. Plough \& Gass, 1993). The former is a form of TR that entails repeating a familiar task (i.e., the learner is familiar with the task procedures) varying the content of the task. The latter entails changing procedures while maintaining the same content in the various iterations of the task.

In addition to those studies that have looked into the learning potential of these three forms of TR (i.e., they have investigated the effects of task repetition), others have investigated the effect of task-type repetition, thereby contrasting the learning outcomes of various types of TR, be it exact task repetition and procedural repetition (cf., Kim, 2013), content TR and procedural TR (cf. Mackey, Kanganas, \& Oliver, 2007), or exact TR, content TR, and procedural TR (cf. Patanasorn, 2010).

Globally considered, this research has been guided by three main aims in their analyses of learners' execution of and performance in both monologic and dialogic oral tasks. Most TR studies have looked into the effects of TR or task-type repetition on the characteristics and features of oral production, be it error making and/or use of target forms and structures (cf. Bygate, 1996; Gass et al., 1993; Kim \& Tracy-Ventura, 2013; Patanasorn, 2010), and/or CAF measures of the speech produced (i.e., complexity, accuracy, and fluency, cf. Ahmadian \& Tavakoli, 2010; Bygate, 2001; Kim \& Tracy-Ventura, 2013; Lynch \& Maclean, 2000; Saeedi \& Kazerooni, 2014), looking at both short-term and longer-term changes, in the latter case ranging from 4 weeks (cf. Kim \& Tracy-Ventura, 
2013) to 10 weeks (cf. Bygate, 2001). Another focus of research (be it a focus on performance measures or not) has been the examination of the effects of various forms of TR on attention to language/focus on form while engaged in task execution, operationalized as LREs (language-related episodes), examining at the same time which dimension of language is fostered by task-type repetition (cf. Kim, 2013). A third focus of research has been the analysis of the effects of various forms on TR on the use of discourse and interactional features (cf. Plough \& Gass, 1993; Mackey et al., 2007). In addition, one study (Kim, 2013) looked into students' and teachers' perceptions of the usefulness of TR (a highly critical and relevant pedagogical concern), and three studies (Baleghizadeh \& Derakhshesh, 2012; Hawkes, 2011; Sheppard, 2006, the latter studied here via Ellis, 2009) examined the combined effect of TR and some intervening manipulation of the learner's attention to language before the repetition of the task, be it a FonF session (Hawkes, 2011, a study in which TR is viewed as a form of post-task activity) or the provision of feedback (Baleghizadeh \& Derakhshesh, 2012; Sheppard, 2006). It is worth mentioning that only Sheppard (2006) included a control group who engaged in TR without the availability of feedback and so the results of the other two studies mentioned in this group have to be taken with caution.

Most of the TR empirical studies have been conducted with secondary school learners of English (Gass et al. [1999] being a study of Spanish and Lynch and Maclean [2000] one of the few studies conducted with adult L2 learners). Important for our present purposes is the consideration of the kind of tasks the participants in these studies were asked to perform, which, as mentioned above, included both monologic and dialogic tasks (i.e., performed individually or collaboratively) consisting of retelling stories and/or content of videos and silent films (cf. Bygate, 1996, 2001; Bygate \& Samuda, 2005; Gass et al., 1999; Patanasorn, 2010), as well as various forms of interactive tasks (with both learner-learner and learnerteacher interaction), such as poster carousel (Lynch \& Maclean, 2000), interviews (Bygate, 2001), or various forms of information exchange tasks based on prompts (cf. Kim, 2013; Kim \& Tracy-Ventura, 2013).

Collectively considered, the body of knowledge accumulated has provided empirical support to the purported language-learning gains that 
may derive from both task repetition and task-type repetition. Repetition of the same task has systematically been found to have a positive effect on attention to language and most available studies have found an increase in measures of complexity, fluency and, to a lesser extent, accuracy as a result of engaging in some form of TR. However, no empirical evidence has been obtained on the carryover of effects of TR to a new (similar or identical) task, which led Ellis (2009) to problematize the purported benefits of TR for L2 acquisition and to wonder whether, as suggested by Bygate (2001), for TR to assist acquisition, the crucial variable may be 'massed' repetition practice, or the learner's access to "some kind of feedback on their initial performance of the task" (p. 477), as would otherwise be the norm in writing. These are empirical questions worthy of attention in future research agendas.

There is also indication that task-type repetition does have an effect on the dimensions of language attended to in the second iteration of the task although research findings in this area are not consistent. For instance, Kim and Tracy-Ventura (2013) found that procedural TR (in contrast to exact task repetition) resulted in improved syntactic complexity, whereas Kim (2013) found that repeating the same task with different content (i.e., procedural task repetition) elicited more attention to both lexis and grammar, as compared with students who repeated the same task with exact content. This led the author to suggest that "repeating tasks with the same procedure may help learners elaborate their ideas by using new expressions because of the extra attention available to focus on linguistic forms (both lexical and grammatical) during task performance" (Kim, 2013, p. 18). However, Gass et al. (1999) examined the effects of content repetition and found that repeating the same task with different content (i.e., procedural repetition) led to higher gains in grammatical accuracy whereas repeating tasks with the same content (i.e., content repetition) had a positive effect on lexical sophistication. Patanasorn (2010) also found increases in accuracy as a result of procedural repetition, whereas content repetition was found to lead to increases in fluency measures. Therefore, further studies are needed before more robust conclusions about the effects of task-type repetition can safely be reached. 
Research on TR to date is also limited in other ways. It is important to reiterate that developmental concerns have not been sufficiently explored in TR empirical research agendas, including analyses of the long-term effects of TR, the transfer of learning effects to new tasks, or whether or not the purported learning outcomes that may derive from TR are dependent on the number of repetitions.

Teacher-related and learner-related factors-crucially, motivational issues - (see Gass et al., 1999; Kim, 2013) in bringing about learning benefits through TR are also relevant items for future research agendas. Future advancements are equally dependent on expanding the range of tasks investigated and the populations studied as scarce research exists on how and, if so, why, more advanced and older L2 learners may benefit from which type of TR in the short- and long-term. Importantly, with the exception of Nitta and Baba's (2014) study (to be analyzed in the next section), L2 writing has been absent in the TR theoretical and empirical research. Why writing should be made more central in future TR research has already been mentioned in earlier sections and reference has also been made to the distinct effects that TR may have in the domain of writing on account of the variations in time processing constraints that characterize the execution of oral and writing tasks. In the next section, I go deeper into the characterization of TR in the writing environment and I explore questions in need of attention in future research agendas.

\section{Task Repetition in Writing: Nature and Potential Learning Effects}

As I argued in Manchón (2014b), the analysis of TR in the domain of writing would benefit from adopting, and partially expanding, the dual distinction established by Bygate (2006) between "internal task repetition" and "external task repetition", a dichotomy that he used as a criterion to classify oral tasks. I will borrow Bygate's categories not only to examine the typology of TR alternatives in writing, but also, and more importantly, to try and ascertain questions worth asking when investigating the manner in which repetition of writing tasks can assist acquisition. 


\section{a. External Task Repetition}

Bygate's (2006) characterized external repetition as "repetition where the task requires students to repeat their talk to different students" (p. 173). Although the examples provided by Bygate would equate external TR with the type of "exact task repetition" mentioned in the previous section, his concept of external TR can also be made to encompass the other two TR modalities explored in empirical research, namely, procedural repetition and content repetition, as discussed above. To the best of my knowledge, Nitta and Baba (2014) is the only study that has investigated external TR in the writing domain, in their case looking into the long-term effects of tasktype repetition. Framed in Dynamic Systems Theory, their study followed forty-six first-year Japanese university EFL students over a period of 40 weeks. The participants wrote a composition on a chosen topic for ten minutes each week, which were analyzed using five indices of fluency, lexis, and grammar. Their results showed that whereas mere task repetition had limited effects, task-type repetition did have a marked effect on the lexical and grammatical dimensions of the written texts produced. Interestingly, the researchers also observed a developmental trend in the effects of tasktype repetition, moving from an original increase in fluency towards a gradual improvement in the domains of lexical and syntactic complexity over the course of the 40 weeks the study lasted. This is an interesting finding on the dynamics on the acquisitional outcomes that may derive from external task-type repetition and one worth exploring further in future studies. The study also provides empirical evidence to previous claims in the oral domain (cf. Bygate, 2001; Ellis, 2009) regarding the crucial role played by massed repetition in bringing about expected learning gains.

There is another dimension of external TR in writing worthy of attention: Discussions of external TR in the writing domain necessarily need to acknowledge the role that the provision and processing of feedback may play in the external TR cycle. Arguably, it makes all pedagogical sense to investigate external TR in writing with the availability of feedback because research on feedback on writing systematically shows that although simply repeating the same tasks is likely to render benefits at some level (i.e., the 
text is better in terms of language and/or content), rewriting after receiving and processing feedback always brings about greater and more enduring benefits. However, this is another area in which research on long-term effects of TR is scarce, as discussed in the concluding section.

\section{b. Internal Task Repetition}

In contrast to the kind of repetition subsumed under the category of external TR, “internal repetition" in Bygate's terms "is repetition which is encouraged by the demands of processing the input material and/or of preparing the intended task outcome" (Bygate, 1996, p. 173). Bygate (1996) further argued that internal repetition results from the pressure on the students "to manage the different phases of the task" (p. 176). It is worth noting that theoretical accounts of TR and empirical investigations of TR in the oral domain have ignored internal TR. In contrast, I would like to suggest that the study of internal TR should be made a central concern in future research agendas of TR in writing.

We can reformulate Bygate's characterization of TR by proposing that internal TR in the domain of writing would apply to cases in which, rather than being externally imposed by the task instructions and/or the feedback received on one's own writing, the repetition is an integral part of the successful completion of the writing task itself as a function of its inherent complexity and processing demands. In this respect, Bygate's classification of tasks into external TR tasks and internal TR tasks is reminiscent of a well-known distinction in the writing field between "knowledge telling" and "knowledge-transforming" writing (Bereiter \& Scardamalia, 1987; Scardamalia \& Bereiter, 1987). The main differences between them relate to how ideas for writing are generated, as well as to the amount and intensity of problem solving involved, or, in their own words, "how knowledge is brought into the writing process and in what happens to knowledge in that process" (Scardamalia \& Bereiter, 1987, p. 143). Accordingly, knowledge telling is a kind of sequential style of writing in which ideas flow as a process of association along a chain of 
conceptual relations, usually resulting in the type of "what-next" strategy that characterizes child writing or immature adult writing. Scardamalia and Bereiter (1987) suggested that in this kind of writing writers simply "tell" knowledge, which means that the writing process can proceed without an overall plan or specific goal setting procedures and, hence, without engaging in the kind of problem-solving behavior that characterizes expert writing. In contrast, knowledge transforming entails problem solving, which is seen as the interaction between two problems spaces, content and rhetorical. The content problem space refers to the writer's knowledge and beliefs about the topic, whereas the rhetorical space refers to the writer's beliefs about the text and the goals of the task at hand. This would correspond to the kind of writing usually referred to as a cognitively demanding problem-solving task which ultimately entails both strategic decisions regarding the allocation of attentional resources to the various demands encountered in the act of composing, and, crucially, an intense linguistic activity that, in the case of L2 writing, Cumming (1990) rightly characterized as "reasoning about linguistic choices" (p. 491). Interestingly, the latest models of writing (cf. Hayes, 2012a, 2012b) put the process of text generation (i.e., the conversion of ideas into language) center stage (see Manchón, 2014b).

My claim would be that the concept of internal TR applies mainly to knowledge-transforming writing tasks, those in which the task execution entails engaging in problem analysis, goal setting, and problem-solving behavior as a result of the "demands of processing the input material and/ or of preparing the intended task outcome" that Bygate assigns to tasks that entail internal task repetition (Bygate, 1996, p. 173). Let me mention in passing that most of the tasks used in the available empirical research on TR would be closer to the knowledge-telling rather than the knowledgetransforming end of the continuum. In this sense, writers engage in knowledge telling when the goal (self-imposed or other-imposed) is to convey information already available, either because it is already stored in one's memory stores or made available with the task instructions. This would be the case of reproducing in writing the kind of retelling tasks or information exchange tasks used in previous studies of TR with oral tasks. 
There are two further aspects of the internal dimension of knowledge-transforming writing tasks worth mentioning, even if briefly (see Manchón, 2014b for a fuller elaboration), as these are distinctive characteristics of writing that contribute to the differential nature of TR in speaking and writing tasks. These refer to the recursiveness of the writing process, on the one hand, and the concept of task representation and its dynamism in writing, on the other.

The concept of "recursiveness" refers to the interaction among writing processes throughout the composing process and the constant interaction between "reflection and text production processes" taking place not only within but also across drafts (Galbraith, van Waes, \& Torrance, 2007, p. 5). This interaction contrasts with the sequence of conceptualization, formulation, and articulation that characterizes speaking. In fact, the purported benefits of TR in speaking are based on the assumption that repetition of a task would facilitate attention to form (i.e., formulation and articulation) once the conceptualization of the message has been prioritized. This is how Bygate (1996) explains these potential benefits (p. 170):

we should expect that on the first occasion they will spend more effort than normal on the content of what they want to say, and on finding as quickly as possible words that will express the meanings. If learners then repeat a speech activity, or at least significant elements of the activity, this will lead them to have to allocate less attention to the content, and enable them to allocate more attention to how the content is expressed, than they did first time around. That is, on repetition their attention would be expected to shift from the content, to the form, with the result that grammatical details are gradually integrated into the whole.

The situation might not be exactly the same in writing given that writers continuously shift attention among idea generation, planning content or procedures, text generation, and revision and evaluation processes, with the result that the sequence of these processes is not linear but rather recursive, entailing a continuous interaction among processes. This recursive nature of writing processes results in the distinct internal 
task repetition nature of the meaning-making activity that characterizes complex, goal-oriented, problem-solving writing.

Closely linked to the previous point is a final factor contributing to the idiosyncratic nature of internal TR in writing, namely, the potential dynamism of how the writer may represent the task at hand. This is a crucial concern in cognitive accounts of writing that has otherwise been absent in previous theory and research on TR, may be as a consequence of the kind of knowledge-telling tasks that form the basis of extant research. Task representation in writing refers to the writer's understanding of the rhetorical problem posed by the task. This representation is purported to guide both the goals that writers set for the completion of the task, and the problem-solving strategies used during task execution. Cognitive models of writing and cognitively-oriented L2 writing research emphasize that task representation, goal setting, and problem-solving activity emerge from the dynamic and evolving interaction between the task environment (including, inter alia, the task prompt and the text written so far) and the writer, rather than being a direct consequence of task conditions alone. Therefore, task representations are unstable, dynamic, and likely to change throughout the composing process thereby resulting in a kind of internal TR that is characteristic of writing and not so much of speaking (see discussion in Manchón, 2014b).

It follows that complex knowledge-transforming tasks entail varying degrees of internal, built-in task repetition that needs to be made an integral part of theorizing on TR and whose potential learning outcomes are worth exploring in future TR empirical research.

\section{Implications for Theory and Research}

I started this paper by emphasizing to the need to make writing more central in SLA theory in research as well as in TBLT preoccupations. I have also argued that the distinctive characteristics of L2 writing and the rich potential that may derive from text generation processes in the time conditions that written communication allows, as well as from the processing of feedback received on one's own writing, would justify the 
reconsideration of some tenets and principles of current TR scholarship, as well as the expansion of empirical research agendas in the field.

At a theoretical level, and assuming that TR should be made to encompass all language modalities, I have presented evidence in support of reconfigurating current understandings of the nature and effects of TR on account of (i) the idiosyncrasy of writing tasks with respect to the timed nature of written communication and the acquisitional benefits that the availability of time may bring about, and (ii) the distinct nature of external and internal TR in the domain of writing.

In terms of external TR, the availability of feedback and the role of feedback in bringing about potential benefits should be made central in future TR preoccupations. Future research agendas on how and why feedback processing as part of the TR cycle may lead to L2 learning include a whole range of empirical questions because, as evidenced in the literature on the language learning potential of WCF (see Bitchener, 2012, for a recent review), the mere provision of WCF does not guarantee potential language gains. Rather, these gains are purported to be crucially dependent on the learners' own engagement with and processing of the feedback received. In turn, there is empirical evidence to posit that the language learning potential that may derive from the learner's own processing of WCF is dependent on feedback factors (which type of feedback is provided and how), task factors (type of writing tasks), linguistic factors (which linguistic elements were targeted in the feedback provided), and individual factors (analytic ability, L2 proficiency, beliefs, goals, and attitudes). Questions for future research, therefore, include the elucidation of the manner in which these range of variables may mediate the potential effects of TR after receiving feedback in the short- and long-term. In fact, the abundant research on written corrective feedback (see recent reviews in Bitchener, 2012; Bitchener \& Ferris, 2012) has shed plenty of light on "uptake" of linguistic forms targeted in the feedback received (and this applies mainly to grammar as lexical issues have attracted much less attention), but little is known about longer-term effects on acquisition, i.e., on "retention." Therefore, research in the field needs to set up a truly acquisitional research agenda, one whose main focus of concern would be what I have previously called "feedback for acquisition," in opposition 
to "feedback for accuracy" (Manchón, 2011c). This research agenda must include items on those variables that may mediate the potential effects on acquisition of the feedback provided, as well as the nature of those effects. As for mediating variables, my own view is that future research agendas need to delve further into the following (Manchón, 2014b, p. 45):

the type of feedback provided (direct/indirect; explicit/implicit; inputproviding/output-pushing); the dimensions or levels targeted in the feedback provided (language, textual, content, audience concerns, among others); the kind of cognitive processes fostered (simple versus deep noticing, problem identification and/or problem solution, noticing and/ or uptake; uptake and/or retention, among others); and the individual or collaborative processing of the feedback received.

In addition to shedding light on the mediating role that the previous variables may play, equally worthy of future empirical attention is the exploration of which acquisitional benefits (i.e., dimensions of retention) may derive from the provision and processing of feedback, crucially including whether or not such outcomes include the expansion and/or consolidation of explicit and/or implicit knowledge about the L2, which in effect are general issues of concern in the theoretical and empirical literature on the language learning potential of L2 writing in general (see Ortega, 2012; Williams, 2012), and of the processing of feedback in particular (see discussions in Bitchener, 2012; Bitchener \& Ferris, 2012. See also Shintani \& Ellis, 2013, for a recent empirical study on feedback and the acquisition of implicit/explicit knowledge in writing).

In short, external TR in writing can take the form of exact TR, content TR and procedural TR, in all cases with the theoretically relevant and pedagogically plausible alternative of adding the provision of various forms of feedback at some point in the task repetition cycle. The expected benefits include not only improvements in performance measures, but also longer-term benefits associated with retention. Equally worthy of attention would be to investigate whether or not expected or documented shortterm and long-term effects of external repetition are modality-dependent, which ultimately would entail adding TR concerns to previous research 
on task-modality effects (see analyses of this scholarship in, for instance, Byrnes \& Manchón, 2014b; Kuiken \& Vedder, 2012. For recent taskmodality effects studies, see Kormos, 2014; Tavakoli, 2014). Similarly, and in line with some of the future avenues for research in the oral domain, future research agendas should make room for the exploration or three key issues: (i) whether it is repetition per se or task-type repetition that can bring about learning benefits, and, following from here, whether it is more pedagogically sound to opt for task repetition or for task variation in terms of the language-learning potential each option may foster (Manchón, 2014a), (ii) the way in which these learning benefits may be mediated by the intensity of TR and its duration, and (iii) which benefits may derive from more and less intense/durable task repetition/task-type repetition procedures when writing is performed individually vs. in collaborative writing conditions, in both cases in pen-and-paper and computer-mediated environments.

Open questions also exist with respect to the characteristic internal task repetition nature of complex, knowledge-transforming writing tasks. In this respect, we still need to know which language-learning benefits may derive from the engagement in more knowledge-transforming tasks, thereby searching for empirical evidence on the purported languagelearning potential associated with the problem-solving activity that knowledge-transforming tasks entail (see Byrnes \& Manchón, 2014b, 2014c; Manchón, 2011b; Manchón \& Roca de Larios, 2007, 2011). Open questions also exist on whether or not these potential benefits are mediated by task-related factors (such as task instructions, scaffolding provided throughout the task cycle, in individual and collaborative environments, or the task complexity factors contemplated in Robinson's and Skehan's theorizing), learner-related factors (especially issues of L2 proficiency and writing expertise), as well as the interaction between task factors and learner factors (see Manchón, 2014b for a fuller analysis of this interaction).

It is hoped that the ideas and analysis offered in the paper can represent a starting point for the expansion of the theoretical and empirical task repetition research agendas. This would represent not only a 
concomitant expansion of TBLT theory and research, but also a welcome addition of writing to TBLT and SLA preoccupations, an addition of highest theoretical and applied relevance.

\section{Acknowledgements}

This paper is part of a research project on the language learning potential of writing currently underway at the University of Murcia, Spain, supported by a research grant from the Fundación Séneca, Murcia Regional Government Agency for Science and Technology (Research Grant 11942/PHCS/09), and a grant by the Spanish Ministry of Economy and Competiveness (Research Grant FFI2012-35839).

\section{References}

Ahmadian, M. J., \& Tavakoli, M. (2010). The effects of simultaneous use of careful online planning and task repetition on accuracy, complexity, and fluency in EFL learners' oral production. Language Teaching Research, 15, 35-59. http://dx.doi.org/10.1177/1362168810383329

Baleghizadeh, S., \& Derakhshesh, A. (2012). The effect of task repetition and noticing on EFL learners' oral output. International Journal of Instruction, $5,141-152$.

Bereiter, C., \& Scardamalia, M. (1987). The psychology of written composition. Hillsdale, NJ: Lawrence Erlbaum.

Bitchener, J. (2012). A reflection on the language learning potential of written CF. Journal of Second Language Writing, 22, 348-363. http://dx.doi. org/10.1016/j.jslw.2012.09.006

Bitchener, J., \& Ferris, D. (2012). Written corrective feedback in second language acquisition and writing. London: Routledge.

Bygate, M. (1996). Effects of task repetition: Appraising the developing language learners. In J. Willis \& D. Willis (Eds.), Challenge and change in language teaching (pp. 136-146). Oxford: Heinemann.

ELIA 14, 2014, pp. 13-41 DOI: http://dx.doi.org/10.12795/elia.2014.i14.02 
Bygate, M. (2001). Effects of task repetition on the structure and control of language. In M. Bygate, P. Skehan, \& M. Swain (Eds.), Researching pedagogic tasks: Second language learning, teaching, and assessment (pp. 23-48). London: Longman.

Bygate, M. (2006). Areas of research that influence L2 speaking instruction. In E. Usó-Juan \& A. Martínez-Flor (Eds.), Current trends in the development and teaching of the four languageskills (pp.159-186). Berlin: Mouton De Gruyter. http://dx.doi.org/10.1515/9783110197778.3.159

Bygate, M., \& Samuda, V. (2005). Integrative planning through the use of task- repetition. In R. Ellis (Ed.), Planning and task performance in a second language (pp. 37-74). Amsterdam: John Benjamins. http://dx.doi. org/10.1075/11lt.11.05byg

Bygate, M., van den Branden, K., \& Norris, J. (2014). Series editors' preface. In H. Byrnes \& R. M. Manchón (Eds.), Task-based language learning: Insights to and from writing (pp. ix-xi). Amsterdam: John Benjamins.

Byrnes, H., \& Manchón, R. M. (2014a). Task-based language learning: Insights to and from writing. Amsterdam: John Benjamins.

Byrnes, H., \& Manchón, R. M. (2014b). Task-based language learning: Insights from and for L2 writing. An introduction. In H. Byrnes \& R. M. Manchón (Eds.), Task-based language learning: Insights to and from writing (pp. 1-23). Amsterdam: John Benjamins.

Byrnes, H., \& Manchón, R. M. (2014c). Task, task performance, and writing development: Advancing the constructs and the research agenda. In $\mathrm{H}$. Byrnes \& R. M. Manchón (Eds.), Task-based language learning: Insights to and from writing (pp. 267-299). Amsterdam: John Benjamins.

Cumming, A. (1990). Metalinguistic and ideational thinking in second language composing. Written Communication, 7, 482-511. http://dx.doi. org/10.1177/0741088390007004003

Ellis, R. (2009). The differential effects of three types of task planning on the fluency, complexity, and accuracy in L2 oral production. Applied Linguistics, 30, 474-509. http://dx.doi.org/10.1093/applin/amp042

ELIA 14, 2014, pp. 13-41～DOI: http://dx.doi.org/10.12795/elia.2014.i14.02 
Ellis, R. (2012). Language teaching research and language pedagogy. Oxford: Wiley-Blackwell. http://dx.doi.org/10.1002/9781118271643

Ferris, D., \& Hedgcock, J. (2014) (3rd ed.). Teaching L2 composition. Purpose, process, and practice. New York/London: Routledge/Taylor \& Francis.

Galbraith, D., van Waes, L., \& Torrance, M. (2007). Introduction. In M. Torrance, L. van Waes \& D. Galbraith (Eds.), Writing and cognition. Research and applications (pp. 1-10). Oxford: Elsevier.

Gass, S., Mackey, A., Alvarez-Torres, M. J., \& Fernández-García, M. (1999). The effects of task repetition on linguistc output.Language Learning, 49, 549-581. http://dx.doi.org/10.1111/0023-8333.00102

Harkalau, L. (2002). The role of writing in classroom second language acquisition. Journal of Second Language Writing, 11, 329-350. http://dx.doi. org/10.1016/S1060-3743(02)00091-7

Hawkes, M. L. (2011). Using task repetition to direct learner attention and focus on form. ELT Journal, 12, 1-10.

Hayes, J. R. (2012a). Modelling and remodling writing. Written Communication, 29, 369-388. http://dx.doi.org/10.1177/0741088312451260

Hayes, J. R. (2012b). Evidence from language bursts, revision, and transcription for translation and its relation to other writing processes. In M. Fayol, D. Alamargot, \& V. W. Berninger (Eds.), Translation of thought to written text while composing. Advancing theory, knowledge, research, methods, tools, and applications (pp. 15-25). London: Psychology Press.

Housen, A., Kuiken, F., \& Vedder, I. (Eds.). (2012). Dimensions of $L 2$ performance and proficiency. Complexity, accuracy and fluency in SLA. Amsterdam: John Benjamins. http://dx.doi.org/10.1075/11lt.32

Kim, Y. (2013). Promoting attention to form through task repetition in a Korean EFL context. In K. McDonough \&A. Mackey (Eds.), Second languageinteraction in diverse educational settings (pp. 3-24). Amsterdam: John Benjamins. http://dx.doi.org/10.1075/11lt.34.04ch1

ELIA 14, 2014, pp. 13-41～DOI: http://dx.doi.org/10.12795/elia.2014.i14.02 
Kim, Y., \& Tracy-Ventura, N. (2013). The role of task repetition in L2 performance development: What needs to be repeated during task-based interaction? System, 41, 829-840. http://dx.doi.org/10.1016/j.system.2013.08.005

Kormos, J. (2012). The role of individual differences in L2 writing. Journal of Second Language Writing, 21, 390-403. http://dx.doi.org/10.1016/j.jslw.2012.09.003

Kormos, J. (2014). Differences across modalities of performance: An investigation of linguistic and discourse complexity in narrative tasks. In H. Byrnes \& R. M. Manchón (Eds.), Task-based language learning: Insights to and from writing (pp. 193-216). Amsterdam: John Benjamins.

Kuiken, F., \& Vedder, I. (2012). Speaking and writing tasks and their effects on second language performance. In S. Gass \& A. Mackey (Eds.), The Routledge handbook of second language acquisition (pp. 364-377). London: Routledge.

Levelt, W. J. M. (1989). Speaking: From intention to articulation. Cambridge, MA. MIT Press.

Lynch, T., \& Maclean, J. (2000). Exploring the benefits of task repetition and recycling for classroom language learning. Language Teaching Research, 4, 221-250.

Mackey, A., Kanganas, A. P., \& Oliver, R. (2007). Task familiarity and interactional feedback in child ESL classrooms. TESOL Quarterly, 40, 107-132.

Manchón, R. M. (Ed.). (2009). Writing in foreign language contexts: Learning, teaching, and research. Bristol: Multilingual Matters.

Manchón, R. M. (Ed.). (2011a). Learning-to-write and writing-to-learn in an additional language. Amsterdam: John Benjamins. http://dx.doi. org/10.1075/11lt.31

Manchón, R. M. (2011b). Writing to learn the language: Issues in theory and research. In R. M. Manchón (Ed.), Learning-to-write and writing-tolearn in an additional language (pp. 61-82). Amsterdam: John Benjamins. http://dx.doi.org/10.1075/1llt.31.07man

ELIA 14, 2014, pp. 13-41～DOI: http://dx.doi.org/10.12795/elia.2014.i14.02 
Manchón, R. M. (2011c). The language learning potential of writing in foreign language contexts: Lessons from research. In M. Reichelt \& T. Cimasko (Eds.), Foreign language writing. Research insights (pp. 44-64). West Lafayette, IN: Parlor Press.

Manchón, R. M. (2012). L2 writing development: Multiple perspectives. Berlin: De Gruyter Mouton.

Manchón, R. M. (2014a). Learning and teaching writing in the FL classroom: Fostering writing-to-learn approaches. In P. Driscoll, E. Macaro, \& A. Swarbrick (Eds.), Debates in modern language education (pp. 96-107). London: Routledge.

Manchón, R. M. (2014b). The internal dimension of tasks: The interaction between task factors and learner factors in bringing about learning through writing. In H. Byrnes \& R. M. Manchón (Eds.), Task-based language learning: Insights to and from writing (pp. 27-52). Amsterdam: John Benjamins.

Manchón, R. M., \& Roca de Larios, J. (2007). Writing-to-learn in instructed language learning contexts. In E. A. Soler \& M. P. Safont Jordá (Eds.), Intercultural language use and language learning (pp. 101-121). Berlin: Springer. http://dx.doi.org/10.1007/978-1-4020-5639-0_6

Manchón, R. M., \& Roca de Larios, J. (2011). Writing to learn in FL contexts: Exploring learners' perceptions of the language learning potential of L2 writing. In R. M. Manchón (Ed.), Learning-to-write and writing-to-learn in an additional language (pp. 181-207). Amsterdam: John Benjamins. http://dx.doi.org/10.1075/11lt.31.13man

Muranoi, H. (2007). Output practice in the L2 classroom. In R. DeKeyser (Ed.), Practice in a second language: Perspectives from applied linguistics and cognitive psychology (pp. 51-84). Cambridge: CUP.

Nitta, R., \& Baba, K. (2014). Task repetition and L2 writing development: A longitudinal study from a dynamic systems perspective. In H. Byrnes \& R. M. Manchón (Eds.), Task-based language learning: Insights to and from writing (pp. 107-136). Amsterdam: John Benjamins.

Norris, J., \& Ortega, L. (2009). Towards an organic approach to investigating CAF in instructed SLA: The case of complexity. Applied Linguistics, 30, 555578. http://dx.doi.org/10.1093/applin/amp044

ELIA 14, 2014, pp. 13-41 DOI: http://dx.doi.org/10.12795/elia.2014.i14.02 
Ortega, L. (2011). Reflections on the learning-to-write and writing-to-learn dimensions of second language writing. In R. M. Manchón (Ed.), Learningto-write and writing-to-learn in an additional language (pp. 237-250). Amsterdam: John Benjamins. http://dx.doi.org/10.1075/1llt.31.16ort

Ortega, L. (2012). Epilogue: Exploring L2 writing-SLA interfaces. Journal of Second Language Writing, 21, 404-415. http://dx.doi.org/10.1016/j.jslw.2012.09.002

Patanasorn, C. (2010). Effect of procedural content and task repetition on accuracy and fluency in an EFL context. Unpublished Doctoral Dissertation, Northern Arizona University.

Plough, L, \& Gass, S. (1993). Interlocutor and task familiarity: Effects on interaction structure. In G. Crookes \& S. Gass (Eds.), Tasks and language learning: Integrating theory and practice (pp. 35-56). Clevedon: Multilingual Matters.

Polio, C. (2012). The relevance of second language acquisition theory to the error correction debate. Journal of Second Language Writing, 21, 375-389. http://dx.doi.org/10.1016/j.jslw.2012.09.004

Polio, C., \& Williams, J. (2009). Teaching and testing writing. In M. H. Long \& C. J. Doughty (Eds.) The handbook of language teaching (pp. 476-517). Oxford: Blackwell. http://dx.doi.org/10.1002/9781444315783.ch26

Robinson, P. (2007). Criteria for classifying and sequencing pedagogic tasks. In M. P. García-Mayo (Ed.), Investigating tasks in formal language learning (pp. 7-26). Clevedon, UK: Multilingual Matters.

Robinson, P. (2011). Second language task complexity, the Cognition Hypothesis, language learning, and performance. In P. Robinson (Ed.), Second language task complexity. Researching the Cognition Hypothesis of language learning and performance (pp. 3-37). Philadelphia/Amsterdam: John Benjamins. http://dx.doi.org/10.1075/tblt.2

Robinson, P., \& Gilabert, R. (2013). Task-based learning: Cognitive underpinnings. In C. Chapelle (Ed.), Encyclopedia of applied linguistics. Malden, MA: Wiley-Blackwell. DOI: 10.1002/9781405198431.wbeal143.

ELIA 14, 2014, pp. 13-41～DOI: http://dx.doi.org/10.12795/elia.2014.i14.02 
Roca de Larios, J. (2013). Second language writing as a psycholinguistic locus for L2 production and learning. Journal of Second Language Writing, 22, 444-445. http://dx.doi.org/10.1016/j.jslw.2013.08.009

Saeedi, M., \& Kazerooni, S. R. (2014). The influence of task repetition and task structure on EFL leaners' oral narrative retellings. Innovation in Language Learning and Teaching, 8, 116-131. http://dx.doi.org/10.1080/17501229.2 013.770860

Samuda, V., \& Bygate, M. (2008). Tasks in second language learning. New York: Palgrave Macmillan.

Scardamalia, M., \& Bereiter, C. (1987). Knowledge telling and knowledge transforming in written composition. In S. Rosenberg (Ed.), Advances in applied psycholinguistics (pp. 141-175). Cambridge: CUP.

Sheppard, C. (2006). The effects of instruction directed at the gaps second language learners noticed in their oral production. Unpublished $\mathrm{PhD}$ Thesis, University of Auckland.

Shintani, N., \& Ellis, R. (2013). The comparative effect of direct written corrective feedback and metalinguistic explanation on learners' explicit and implicit knowledge of the English indefinite article. Journal of Second Language Writing, 22, 286-306. http://dx.doi.org/10.1016/j.jslw.2013.03.011

Skehan, P. (1998). A cognitive approach to language learning. Oxford: University Press.

Skehan, P. (2014). The context for researching a processing perspective on task performance. In P. Skehan (Ed.), Processing perspectives on task performance (pp. 1-26). Philadelphia/Amsterdam: John Benjamins. http:// dx.doi.org/10.1075/tblt.5

Storch, N. (2013). Collaborative writing in L2 classrooms. Bristol: Multilingual Matters.

Swain, M. (1985). Communicative competence: Some roles of comprehensible input and comprehensible output in its development. In S. Gass \& C. Madden (Eds), Input in second language acquisition (pp. 235-253). Rowley, Mass.: Newbury House.

ELIA 14, 2014, pp. 13-41～DOI: http://dx.doi.org/10.12795/elia.2014.i14.02 
Swain, M. (1995). Three functions of output in second language learning. In G. Cook \& B. Seidlhofer (Eds.), Applied linguistics. Studies in honour of $H$. G. Widdowson (pp. 125-144). Oxford: Oxford University Press.

Tavakoli, P. (2014). Storyline complexity and syntactic complexity in writing and speaking tasks. In H. Byrnes \& R. M. Manchón (Eds.), Task-based language learning: Insights to and from writing (pp. 217-236). Amsterdam: John Benjamins.

Williams, J. (2012). The potential role(s) of writing in second language development. Journal of Second Language Writing, 21, 321-331. http:// dx.doi.org/10.1016/j.jslw.2012.09.007

First version received: October 2014 Final version accepted: November 2014

ELIA 14, 2014, pp. 13-41 DOI: http://dx.doi.org/10.12795/elia.2014.i14.02 